回回回回回回回回回回回回回回回回回回回回回回回

Problemy istorii, filologii, kul'tury

4 (2017), 412-418

(C) The Author(s) 2017

Проблемы истории, филологии, культуры 4 (2017), 412-418

(с)Автор(ы) 2017

\title{
INTERACTION BETWEEN METAPHORS AND THEIR NON-METAPHORICAL SURROUNDINGS IN POLITICAL TEXTS: MODELS OF IDENTITY AND OPPOSITION
}

\author{
Wang Jianing, Tatyana M. Voronina \\ Ural Federal University named after the first President of Russia B.N. Yeltsin, \\ Yekaterinburg, Russia \\ 805870962@qq.com; tmv313@ya.ru
}

Abstract. Conceptual metaphors can be realized not only on the level of words, phrases and sentences, but also on the level of text. Since there is vast research literature on extended conceptual metaphors (both sustained and original) in media texts, we focused on models of interaction between the metaphor and its non-metaphorical textual surroundings. We analyzed political media texts and identified the following types of interaction: models of identity and models of opposition. In models of identity, the meaning of the metaphorical model corresponds to that of the non-metaphorical context. Either both elements of the model play an equal part in conveying the main meaning of the text or one of them prevails. In models of opposition, one language expression can be interpreted both in its direct and metaphorical meaning (or meanings), each of them corresponding to one element in the non-metaphorical context and contradicting another. As the text unfolds, these models play the pivotal role since they ensure the text's integrity and coherence and enhance its pragmatic effect.

Keywords: conceptual metaphor, political text, metaphor in the text, extended metaphor, modelling, identity, opposition

Modern studies show that conceptual metaphor exists and is realized not only on the level of words, phrases and sentences but also on the level of text. A special emphasis is placed on the role metaphor plays in organizing the text and in ensuring its coherence and integrity. L.G. Babenko points out the importance of such text characteristics as consistency and extendedness: she believes that, found on the surface level of the text, which is a linear sequence of words, sentences, and superphrase unities, these characteristics are primarily related to the text's semantic unfolding and the sequence of meanings on the deeper level ${ }^{1}$. Studies of the process of the text unfolding itself

Ван Цзянин - аспирант кафедры современного русского языка и прикладной лингвистики Уральского федерального университета им. первого Президента России Б.Н.Ельцина.

Воронина Татьяна Михайловна - кандидат филологических наук, доцент кафедры современного русского языка и прикладной лингвистики Уральского федерального университета им. первого Президента России Б.Н. Ельцина.

Исследование выполнено при финансовой поддержке РФФИ (проект № 16-06-00340 «Отношения противоположности в словаре и дискурсе: лексикографический когнитивно-дискурсивный и лингвокультурологический аспекты»), а также при поддержке Программы повышения конкурентноспособности УрФУ на 2013-2020 гг. (номер соглашения 02.А03.21.0006).

1 Babenko, Kazarin 2005, 43.

CC IA RAS, NMSTU, JHPhCS, 2017| DOI 10.18503/1992-0431-2017-4-58-412-418 
and the metaphorical means it employs require a dynamic approach while 'research of the dynamics of metaphorization requires us to consider metaphor primarily as a textual phenomenon'2. Initially such studies focused on literary texts but nowadays they also deal with functions of metaphors in media texts, including political ones. For instance, K.S. Filatov demonstrates that 'in media texts, metaphorical elements are used not sporadically but systematically and not only serve as means of creating images but organize the whole textual structure. Thus, metaphors play a key role in text formation'? Liao Meizhen contends that metaphorical fragments of the text are organized through projection of two domains and their implications ${ }^{4}$. N.G. Shekhtman uses the term 'coherence of imagery': 'an extended metaphorical model (especially if it includes the title of the text) can ensure coherence of imagery and create relations of prospection and retrospection, which, in their turn, enhance coherence of the political text and ensure its comprehensive perception'5. A.P. Chudinov also points out the pragmatic function of metaphors: 'extended conceptual metaphor (along with other means) can provide coherence and integrity of the text, enhance its aesthetic significance and pragmatic potential and accentuate its semantic and emotional integrity' ${ }^{6}$.

There exists vast research literature on the ways of extending conceptual metaphors (sustained or original) in media texts. A.P. Chudinov points out that apart from one dominant model, there can be two or three models realized simultaneously: he analyzes the relationship between the metaphorical title of an article and its main text and reveals such literary strategies as defeated expectancy, enhanced expectancy, and fulfilled expectancy ${ }^{7}$.

In this article, instead of focusing on models of extended metaphors in texts, we will be discussing models of interaction between such metaphors and their non-metaphorical textual surroundings. We have analyzed over thirty articles published between 2015 and 2017 in the political section of Russian on-line newspaper 'Gazeta.ru' (https://www. gazeta.ru/politics).

As a result, we have identified the following models of interaction between the metaphor $(m$ or $M)$ and its non-metaphorical context ( $\mathrm{nm}$ or $N M)$ : models of identity and opposition. Capital letters in these abbreviations denote prevalence of the metaphor or its non-metaphorical context in conveying the main meaning of the text.

Let us consider models of identity first.

1. Model of identity $M=N M$. Metaphorical and direct meanings of words and phrases are realized simultaneously to create a single effect and to make an evaluative comment. For example:

Diplomat vysokogo poleta (High-flying diplomat) $(21.03 .2017,17: 34)$

Zakharova rasskazala kak Lavrov otprazdnoval svoy den rozhdenia $v$ samolete (Zakharova reported about Lavrov's celebrating his birthday on a plane)

Svoy 67 den rozhdenia rosskiysky ministr inostrannykh del Sergey Lavrov vstretil 'na vysote', soobshila v feysbuke ofitsialny predstavitel MID RF Maria Zakharova.

\footnotetext{
2 Alekseeva (eds.), Ivinskikh, Mishlanova, Polyakova 2013, 23.

3 Filatov 2014, 159

4 Liao Meizhen 2014, 68

5 Shekhtman 2008, 131.

6 Chudinov 2006, 75.

7 Chudinov 2006, 76-88.
} 
(According to Foreign Ministry spokesperson Maria Zakharova, Russian Foreign Minister Sergey Lavrov celebrated his 67th birthday high up in the air). Lavrov otmetil prazdnik na bortu samoleta iz Yaponii v Moskvu - v ocherednoy raz podcherknuv svoy imidzh professionala, dla kotorogo rabota prevyshe vsego. (Lavrov celebrated this holiday on board the plane from Japan to Moscow, thus once again emphasizing his image of a real professional, who prizes his work above everything else). 'Gazeta.Ru' razbiralas $v$ fenomene Lavrova, kotory bolee desyati let opredelyaet litso otechestvennoy diplomatii. ('Gazeta.Ru' analyzed the phenomenon of Lavrov, who for over a decade has been the key figure of Russian diplomacy).

This text combines the conceptual metaphor associating upward movement with success (the minister is described as successful and efficient) with such words as 'polet' (flight) and 'vysota' (height) being used in their direct meanings. The Russian phrase 'na vysote' is particularly interesting since it is used both in its direct ('at high altitude', 'high up') and metaphorical meaning ('top level', 'top notch').

2. Model of identity $m=N M 1, N M 2, \ldots$ The meaning of the metaphorical model corresponds to that of its immediate non-metaphorical context, with the latter playing the dominant role in conveying the meaning of the text. For example:

Kholodny god dlya Lukashenko (Cold year for Lukashenko) (06.01.2017, 18:50)

Chego zhdat ot rossiysko-belorusskikh otnosheny $v 2017$ godu (What to expect from Russia-Belarus relations in 2017)

K kontsu 2016 goda belorussko-rossiyskie otnoshenia dostigli tochki zamerzania. (By the end of 2016 relations between Russia and Belarus had reached the freezing point). Iz mnozhestva poyavivshikhsya za god konflikov fakticheski ne byl razreshen ni odin. (Out of the numerous conflicts arising during the year, not one was resolved). 'Gazeta.Ru' sobrala prognozy razvitia otnosheny dvukh soyuznykh stran $v$ nastupayushem gody. ('Gazeta.Ru' has gathered forecasts for the development of relations between the two partner states in the coming year). K kontsu 2016 goda politicheskie otnoshenia Minska i Moskvy dostigli rekordnogo pokholodania. (By the end of 2016, political relations between Minsk and Moscow have demonstrated unprecedented cold). Prichem ni $v$ Moskve, ni $v$ Minske ne vidyat perspektiv i putey ikh uluchshenia. (What is more, neither Moscow nor Minsk government see the future of this relationship or ways to improve it). Obe storony ostalis pri svoikh obidakh $i$ ne idut na kompromissy. (Both states harbour hard feelings against each other and are not ready to make compromises). $V$ dekabre Rossia tak $\boldsymbol{i}$ ne soglasilas ni na odin belorussky variant razreshenia 'neftegazovogo krizisa', perenesya peregovory o postavkakh uglevodorodov na 2017 god. (In December, Russia did not agree to any of the solutions to the 'oil crisis' problem proposed by Belarus and suspended the negotiations on the supply of hydrocarbons until 2017). Minskoe rukovodstvo, $v$ svoyu ochered, arestovalo trekh rossiyskikh zhurnalistov na svoey territorii, a president strany Alexandr Lukashenko demonstrativno proignoriroval summity ODKB $i$ EAES, gde Moskva igraet lidiruyushuyu rol. (The Minsk government, in their turn, arrested three Russian journalists on their territory while President Alexandr Lukashenko pointedly ignored the CSTO and EEU summits, in which Moscow plays the leading part). Dlya Lukashenko, vidimo, opasenia isportit otnoshenia s Rossiey uzhe neaktualny. (Apparently, Lukashenko is no longer afraid of jeopardizing the relationship with Russia). Oni uzhe isporcheny, i potomy belorussky lider oshushaet bolshuyu svobodu 
manevra. (This relationship is already damaged and the Belorussian leader now has more freedom of maneuver).

In the title and in the first part of the text the phrases with the meaning of 'freezing' are repeated, which shows the realization of the dominant metaphorical model 'international relations as a climate' ('good relations - warm, bad relations - cold'). The non-metaphorical fragment of the text explores the reasons that led to the deterioration of the relationship (conflicts left unsolved, sides unwilling to compromise, negotiations suspended, the summit pointedly ignored, and so on). At the same time, although the meaning of the metaphorical model is identical to that of the main text, we believe that the role of the text in conveying this meaning prevails over that of the metaphor. In the middle fragment of the text there is a full conformity between the metaphor and its non-metaphorical context: $M=N M 1, N M 2, \ldots$ (the emphasis is made on the relations between the two countries and these relations are seen as cold) but in the title and in the last passage the accent is placed only on one side of the conflict to implicitly convey the author>s opinion that the deterioration of the relationship will mainly affect Belarus but not Russia.

3. Model of identity $M=n m 1, n m 2, \ldots$ The meaning of the metaphorical model corresponds to its non-metaphorical context but the metaphor plays the main role in conveying the meaning of the text. For example:

Putin potreboval perekryt kanaly nelegalnoy migratsii (Putin demanded to block the channels of illegal immigration) $(09.03 .2017,13: 47)$

President Rossii Vladimir Putin potreboval perekryt kanaly nelegalnoy migratsii $v$ stranu, peredaet TASS. (President of Russia Vladimir Putin demanded that the channels of illegal immigration should be blocked, according to TASS). Pri etom on utochnil, chto Rossia budet prinimat tekh, kto khochet zdes zhit i rabotat, sobludaya zakony. (He pointed out that Russia will accept those who want to live and work in the country following its laws). 'My sozdaem tsivilizovannuyu prozrachnuyu sredy dlya tekh, kto khotel by zhit i rabotat $v$ Rossii, no, bezuslovno, sobludaya nashi zakony, uvazhaya traditsii i kulturu nashey strany', - zayavil Putin. ('We are creating a civilized transparent environment for those who would like to live and work in Russia but these people should certainly respect traditions and culture of this country', Putin said). Po ego slovam, 'pri etom kanaly nelegalnoy migratsii, lubye fakty narushenia migratsionnogo zakonodatelstva dolzhny reshitelno presekatsya (He said that 'channels of illegal immigration and any attempts to breach the immigration laws should be firmly dealt with'). Ranee Putin zayavil o neobkhodimosti postavit zaslon na granitsakh Rossii na puti kontrabandy i nelegalnoy migratsii. (Previously Putin asserted that it is necessary to hinder illegal trafficking and immigration on Russian borders).

Thus, the meaning of presence/absence of obstacle is represented through the conceptual metaphor ('block the channels', 'transparent environment') and through the non-metaphorical means ('accept those who want to live and work in the country following its laws', 'any attempts to breach the immigration laws should be firmly dealt with'). However, the metaphorical expressions with the meaning 'creating an obstacle' dominate the text in terms of quantity and occupy 'strong' positions in the text (the title and the last sentence). Thus, the author highlights the idea of curbing illegal immigration while the idea of encouraging legal immigration remains in the periphery. A.P. Chudinov pointed out that the persuasive impact on the reader is stronger if the author resorts to 
metaphorical expressions in comparison with the usage of non-metaphorical means: 'it is well-known that figurative language attracts the reader's attention more and makes writing more powerful' ${ }^{1}$.

Models of the second type - those of opposition - are even more effective in realizing the pragmatic function of metaphors in the text.

4. Model of opposition $N M=(M)_{1} M_{2} \leftrightarrow N M$.

Such model is usually found in texts where one expression can be intepreted both in its direct and metaphorical meaning and one of these meanings contradicts the rest of the text. For example:

Yaponia perekhodit granitsu (Japan is crossing the border) $(15.07 .2015,12: 23)$

Yaponia smozhet osuschestvlyat voennye operatsii za rubezhom. (Japan will be able to carry out military operations abroad).

Profilny komitet nizhney palaty parlamenta Yaponii odobril proekt zakona, $v$ sootvetstvii s kotorym vooruzhennye sily strany mogut vesti boevye deystvia za granitsey. (The special commitee of the lower house of the Japanese parliament passed the bill which allows the country's armed forces to carry out military operations abroad). Protivniki zakonoproekta schitayut, chto on protivorechit konstitutsii strany $i$ mozhet vtyanut yeyo $v$ voennye konflikty po vsemu miru. (Opponents to this bill believe that it contradicts the country's constitution and can embroil the country into military conflicts all over the world) $\langle\ldots\rangle$ V nastoyashy moment idet glubokaya perestroyka politiki Yaponii v oblasti bezopasnosti, - govorit Dmitry Streltsov, - v napravlenii togo, chto v Yaponii nazyvayut 'normalnoy stranoy', ne otyagchennoy nikakimi ogranicheniami. (According to Dmitry Streltsov, at the moment the Japanese policy in the sphere of national security is undergoing a profound transformation leading towards what in Japan is referred to as the 'normal country', that is, free from any restrictions). Proiskhodit postepenny otkaz ot kontseptsii 'patsifistskoy strany'. (The country is gradually abandoning the concept of a 'pacifist state').

In the Russian language, the phrase 'perekhodit granitsu' ('cross the border') in its metaphorical meaning refers to going beyond the accepted limits ('cross the line'). Thus, here we find that the metaphor is in relation of opposition with the non-metaphorical sentence in the last part: 'eto perestroyka v napravlenii togo, chto $v$ Yaponii nazyvayut "normalnoy stranoy"' ('a transformation towards what in Japan is referred to as a "normal country"). If we understand this phrase literally, then it will not contradict the rest of the text. The fact that this phrase was included in the title, however, implies that it was not used as a free phrase and that here we are dealing with the effect of defeated expectancy in its pure form. This might also signify implicit evaluation of the bill as breaking the norms.

4.Another type of the model of opposition is $N M 1=M \leftrightarrow N M 2$. A metaphorical expression can acquire two different indirect meanings, each of them corresponding to one element of the surrounding non-metaphorical context and contradicting another. For example:

NATO zachischaet kontakty $s$ Rossiey (NATO wants to facilitate contacts with Russia) (23.03.2017, 08:57).

\footnotetext{
${ }^{8}$ Chudinov 2006, 65.
} 
Gensek NATO zayavil o vazhnosti kontaktov s Rossiey. (The Secretary General of NATO highlighted the importance of contacts with Russia).

Gensek NATO Jens Stoltenberg zayavil o vazhnosti podderzhivat kontakt $s$ Moskvoy v period napryazhennikh otnosheny. (The Secretary General of NATO Jens Stoltenberg highlighted the importance of maintaining contacts with Moscow in the period of strained relations). Vmeste s tem alians prodolzhaet rassmatrivat Rossiyu $v$ kachestve odnoy iz osnovnykh ugroz i deystvovat vopreki interesam Kremlya. (The Alliance, however, continues regarding Russia as one of the main threats and acting against the Kremlin's interests).

The author juxtaposes the two metaphorical meanings of the verb 'zachistit': its technical meaning 'to clean, to grind to bare metal for better contact and performance' and its military meaning 'to carry out a clearance operation to eliminate enemy forces'.

Thus, our analysis of political media texts has brought to light the following types of interaction between extended conceptual metaphors and their surrounding non-metaphorical context: models of identity and models of opposition. In models of identity, the meaning of the metaphorical model corresponds to the non-metaphorical context. Both elements of the model can play an equal part in conveying the main meaning of the text or one of them can prevail. In models of opposition, one expression can be interpreted both in its direct and metaphorical meaning (or meanings), each of them corresponding to one element in the non-metaphorical context and contradicting another. These models are essential for unfolding the text and not only create its unity and coherence but also enhance the text's pragmatic effect.

\section{ЛИТЕРАТУРА}

Алексеева, Л.М., Ивинских, Н.П., Мишланова, С.Л., Полякова, С.В. 2013: Метафора в дискурсе: учеб. пособие. Пермь.

Бабенко, Л.Г., Казарин, Ю.В. 2003: Лингвистический анализ художественного текста. Теория и практика: учебник: практикум. М.

Филатов, К.С. 2014: Особенности журналистских текстов, развернутых с помощью метафор. Научные ведомости. Сер. Гуманитарные науки 20 (191). Вып. 23, 155-164.

Чудинов, А.П. 2006: Политическая лингвистика. М.

Шехтман, Н.Г. 2008: Реализация текстообразующей функции концептуальной метафоры в политическом тексте. Политическая лингвистика 3 (26), 128-131.

Liao Meizhen 2014: Metaphors we Construct and Organize our Text and Talk by. Foreign language research $176,61-68$.

\section{REFERENCES}

Alexeeva, L.M., Ivinskikh, N.P., Mishlanova S.L., Polyakova, S.V. 2013: Metafora v diskurse: uchebnoe posobie [Metaphor in Discourse: study guide]. Perm.

Babenko, L.G., Kazarin, Y.V. 2003: Lingvisticheskiy analiz khudozhestvennogo teksta. Teoriya $i$ praktika: Uchebnik. Praktikum [Linguistic Analysis of Literary Text. Theory and Practice: Textbook. Workshop]. Moscow.

Chudinov, A.P. 2006: Politicheskaya lingvistika [Political Linguistics: study guide]. Moscow.

Filatov, K.S. 2014: Osobennosti zhurnalistskikh tekstov, razvernutykh s pomoshch'yu metaphor [Characteristics of Media Texts Extended Through Metaphors]. Nauchnye Vedomosti. Ser. 'Humanities' 20 (191). Issue 23, 155-164. 
Liao Meizhen 2014: Metaphors we Construct and Organize our Text and Talk by. Foreign language research $176,61-68$.

Shekhtman, N.G. 2008: Realizatsiya tekstoobrazuyushchey funktsii konceptual'noy metafory v politicheskom tekste [Realization of the Text-Forming Function of the Conceptual Metaphor in Political Text]. Political Linguistics 3 (26), 128-131.

\title{
ИНТЕГРАЦИЯ МЕТАФОРЫ И НЕМЕТАФОРИЧЕСКОГО ОКРУЖЕНИЯ В ПРОСТРАНСТВЕ ПОЛИТИЧЕСКОГО ТЕКСТА: МОДЕЛИ ТОЖДЕСТВА И ПРОТИВОПОСТАВЛЕНИЯ
}

\author{
Ван Цзянин, Т.М. Воронина
}

Уральский федеральный университет имени первого Президента России Б.Н. Ельиина,

Екатеринбург, Россия

805870962@qq.com; tmv313@ya.ru

Аннотация. Современные исследования показывают, что концептуальная метафора существует и реализуется не только в сфере слова и высказывания, но и на уровне целого текста. Достаточно подробно исследованы способы развертывания концептуальной метафоры (как устойчивой, так и авторской) в журналистском тексте. В данной статье акцент делается не собственно на моделях развертывания метафоры в тексте, а на моделях взаимодействия метафоры с неметафорическим окружением в тексте при ее развертывании. На материале политических медиатекстов выявлены следующие виды взаимодействия концептуальной метафоры и ее неметафорического окружения: модели тождества и модели противопоставления. В моделях тождества реализованная метафорическая модель соответствует неметафорическому окружению, при этом оба элемента модели могут быть равноправными при выражении основного смысла текста либо один из них может доминировать. В моделях противопоставления одно языковое выражение можно интерпретировать и в метафорическом, и в прямом смысле (либо в разных метафорических смыслах), каждый из которых соответствует одному элементу неметафорического окружения и противоречит другому. Эти модели важны для развертывания текста и не только работают на создание его целостности и связности, но и участвуют в создании прагматического эффекта.

Ключевые слова: концептуальная метафора, политический текст, метафора в тексте, развернутая метафора, моделирование, тождество, противопоставление 